\title{
Adult Citrus Leafminers (Phyllocnistis citrella) Are Not Efficient Vectors for Xanthomonas axonopodis pv. citri
}

J. Belasque Jr., Fundo de Defesa da Citricultura (Fundecitrus), CP 391, 14901-870, Araraquara, Brazil; A. L. Parra-Pedrazzoli, Departamento de Entomologia, Fitopatologia e Zoologia Agrícola, CP 09, 13418-900, Piracicaba, Brazil; J. Rodrigues Neto, Laboratório de Bacteriologia Vegetal, Instituto Biológico, CP 70, 13001-970, Campinas, Brazil; P. T. Yamamoto, Fundecitrus; M. C. M. Chagas, EMBRAPA/EMPARN, CP 188, 59020-390, Natal, Brazil; J. R. P. Parra, Departamento de Entomologia, Fitopatologia e Zoologia Agrícola; and B. T. Vinyard and J. S. Hartung, United States Department of Agriculture-Agricultural Research Service, Beltsville Agricultural Research Center, Beltsville, MD 20705 USA

\begin{abstract}
Belasque, J., Jr., Parra-Pedrazzoli, A. L., Rodrigues Neto, J., Yamamoto, P. T., Chagas, M. C. M., Parra, J. R. P., Vinyard, B. T., and Hartung, J. S. 2005. Adult citrus leafminers (Phyllocnistis citrella) are not efficient vectors for Xanthomonas axonopodis pv. citri. Plant Dis. 89:590-594.

Interest in the interaction between the citrus leafminer (Phyllocnistis citrella) and citrus bacterial canker, caused by Xanthomonas axonopodis pv. citri, has increased as a greater incidence and severity of canker-diseased plants was observed in groves infested with the citrus leafminer. To determine whether adults of the citrus leafminer could act as vectors of citrus canker, we investigated two potential mechanisms for direct spread by leafminer adults using experimental microcosms. First, adult leafminers were raised on canker-infected foliage and were allowed to mate and lay eggs on healthy plants. These plants then were observed for development of citrus canker symptoms. In a second set of experiments, adults raised on healthy plants were given free access to canker-diseased plants during the period in which they mated and laid eggs on healthy plants. In all, 3,119 mines were produced by developing larvae on a total of 2,384 leaves examined for citrus canker symptoms. No symptoms of citrus bacterial canker disease were observed on any of the healthy test plants in 37 independent experimental trials conducted to test these two potential mechanisms of spread of citrus canker, and the pathogen was not recovered from insects exposed to symptomatic Rangpur lime plants. The upper limit on the rate of transmission was estimated to be less than $0.2 \%$ per oviposition event based on the binomial probability distribution. However, when adult $P$. citrella insects were artificially contaminated with high levels of $X$. axonopodis pv. citri, transmission to Rangpur lime plants with the induction of citrus canker was observed. This suggests that the ability of $P$. citrella to transmit $X$. axonopodis pv. citri is limited by the rate at which it can acquire inoculum from infected plants. The results support the conclusion that adult citrus leafminers are not efficient vectors for citrus canker bacteria, and the disease is unlikely to be spread this way.
\end{abstract}

The citrus leafminer, Phyllocnistis citrella (Lepidoptera: Gracillariidae) Stainton, originated in Asia but now is distributed throughout the five continents where citrus is grown (1). The insect was found in Florida in 1993 and Brazil in 1996, and rapidly became established $(19,21)$. The adult female moth oviposits on very young citrus leaves (shoots), typically when less than $1 \mathrm{~cm}$ of growth has emerged from the bud $(3,9)$. Immediately

Corresponding author: J. S. Hartung

E-mail: hartungj@ba.ars.usda.gov

Financial support of the research was provided by FAPESP and Fundecitrus.

Accepted for publication 4 February 2005.

DOI: 10.1094/PD-89-0590

This article is in the public domain and not copyrightable. It may be freely reprinted with customary crediting of the source. The American Phytopathological Society, 2005. after the larvae emerge from the egg, they penetrate the leaf mesophyll where the larvae develop through four instars, culminating in a pupa from which the adult insect emerges. The larval feeding results in characteristic serpentine mines (galleries), and the associated leaf tissue becomes atrophied, silvery in color, and later necrotic as the mines dry out (4). Reduced photosynthesis, premature leaf drop, and reduced development of shoots are consequences of leaf miner damage, reducing the yield potential of the orchard $(2,5,19,21)$.

The habits of these larvae facilitate the entrance of pathogenic microorganisms into the leaf, especially bacteria of Xanthomonas axonopodis pv. citri (27), the cause of citrus canker, a disease that is present in most citrus-growing regions in the world, including Brazil and Florida, the world's largest producers $(13,24,25)$. Citrus canker symptoms are typified by necrotic, corky lesions, usually surrounded by a yellow halo when they occur on leaves and fruit. In addition, branches also can become infected $(22,25)$. X. axonopodis pv. citri bacteria enter the leaves via the stomata. The most important means of dispersal is wind-driven rain, although long-distance dissemination occurs by transport of infected plants and nursery stock $(7,14,15,20)$. Horticultural activities also can spread the bacteria (11). To curb the spread of citrus canker, the trade in citrus is regulated by strict laws in the main production and importing areas in the world $(13,17,22)$.

Citrus canker has been endemic to Brazil since 1957; however, after the introduction of the citrus leaf miner, the incidence of citrus canker disease dramatically increased (10). The same phenomenon was observed in the United States (12). The cooccurrence of citrus canker and leafminer damage was studied in Yemen (6) and in India (28), where $48.35 \%$ of the leaves showing leaf miner damage also were infected with citrus canker, whereas only $3.18 \%$ of the leaves without leafminer damage showed citrus canker lesions. The severity of citrus canker also was greater on leaves with leafminer damage. In Brazil, the rate of infection of leaves with leafminer damage by $X$. axonopodis pv. citri was 11 times higher compared with undamaged leaves, and was attributed to the hypersusceptible tissue presented to $X$. axonopodis pv. citri by the leafminer galleries (4).

Leafminer damage results in elevated incidence and severity of citrus canker disease $(6,23,28)$, but the role of adult leafminer moths as potential vectors of the bacteria has not been evaluated $(4,16,17)$. Our objective was to determine whether adults of the citrus leafminer can vector citrus canker bacteria directly, either during oviposition or while searching for suitable sites for oviposition.

\section{MATERIALS AND METHODS}

Forty-two experiments were conducted to determine whether adults of the citrus leafminer could vector $X$. axonopodis pv. citri. The experiments were performed in microcosm boxes in a growth room under quarantine conditions. The temperature 
and photoperiod conditions were $28 \pm 1^{\circ} \mathrm{C}$ and light and dark durations of 14 and 10 h, respectively. Rangpur lime (Citrus limonia L. Osbeck) was used in all experiments for both the source and test plants. The plants (25 to $30 \mathrm{~cm}$ tall) were grown in plastic torpedo tubes (20 by $2.7 \mathrm{~cm}$ ), in a vermiculite:plant compost mix $(1: 1)$. The developmental phenology of the plants was monitored to assure that abundant leaf tissue at the optimal stage for oviposition by $P$. citrella was available. $X$. axonopodis pv. citri strain IBSBF 1450 (rifampicin resistant) was used in the experiments. Inoculation of plants with $X$. axonopodis pv. citri was done by immersing the plants in a bacterial suspension in distilled water $\left(10^{7} \mathrm{CFU} / \mathrm{ml}\right)$.

Experimental series I. In these experiments, the objective was to determine whether adult leafminers that emerged from canker-infested galleries could become contaminated with $X$. axonopodis pv. citri and act as vectors of citrus canker during oviposition. In each of these experiments (numbers 1 to 19), 40 Rangpur lime plants infested with eggs or first instar larvae of $P$. citrella were inoculated with $X$. axonopodis pv. citri by immersing the first five leaves of each plant, which contained the eggs or larvae, into the bacterial suspension. These were the canker and leafminer source plants and were maintained in a box made of polystyrene and aluminum (length by width by height $=60$ by 40 by $50 \mathrm{~cm}$ ) with a door at each side and an anti-aphid screen on the back. The canker and leafminer source plants were held in metal racks that were placed in a styrofoam tray containing water, with 40 plants per rack. Subsequent to inoculation, a plastic cover was placed on the back of the boxes in order to increase humidity within the chambers to provide better conditions for plant infection (relative humidity ranged from 90 to $95 \%$ ).

Lesions were observed on the canker and leafminer source plants 12 to 13 days after inoculation. The water contained in the styrofoam tray was removed along with the plastic cover over the back of the boxes and, in 13 experiments (numbers 5 , $6,7,9,10,12,13,14,15,16,17,18$, and 19), the canker and leafminer source plants were sprinkled with water to stimulate exudation of the bacteria from the lesions. In the remaining six experiments in this series (numbers 1, 2, 3, 4, 8, and 11), the leaves of the canker and leafminer source plants remained dry. After removal of the water tray and polythene cover, the relative humidity inside the boxes was 80 to $85 \%$. Forty healthy plants with shoots suitable for oviposition by $P$. citrella adults (test plants) were placed in the boxes beside the source plants. Care was taken so that the canopies of the two sets of plants did not touch. In 16 experiments (numbers 4 to 19), the test plants were sprinkled with water before being introduced into the boxes to provide free water on the surface of the leaves. In 12 experiments (numbers 4,5 , and 7 to 16), needles were used to cause wounds on the young shoots of the test plants. This was done in order to facilitate infection of the leaves by any $X$. axonopodis pv. citri carried by the insect while the insect searched for suitable tissue for oviposition. Both the canker and leafminer source and the test plants were placed in styrofoam trays containing water 5 days after the introduction of the test plants into the boxes. The test plants were assessed for symptoms of citrus canker and the incidence of leafminer damage 15 days after oviposition.

Experimental series II. In these experiments, the objective was to determine whether leafminer adults would acquire inoculum and act as vectors of citrus canker if they were exposed to inoculum only after they emerged from disease-free galleries as adults. Eighteen experiments were conducted sequentially (experiments 20 to 37) with a different set of 40 Rangpur lime plants used as canker sources for each experiment. These source plants were inoculated with a multi-needle pad dipped into a bacterial suspension. Only the first four leaves were inoculated.

The plants were maintained as described above, but a fabric sleeve was attached to a circular opening $20 \mathrm{~cm}$ in diameter in the front of the box. This allowed adult insects raised in the insectary on canker-free plants to be introduced into the boxes, and also allowed the test plants to be introduced into the microcosm while preventing adult insects from escaping. After inoculation with $X$. axonopodis pv. citri, the canker source plants were maintained in a humid chamber for 14 to 16 days to allow time for lesions to develop, at which point the canker source plants were sprinkled with water to stimulate bacterial exudation. In two experiments (numbers 22 and 23), $40 \mathrm{P}$. citrella adults were released into the boxes and then 40 healthy test plants were immediately placed in the boxes beside the canker source plants, such that the adult insects had no exposure to the canker source plants prior to the introduction of the test plants. In the remaining 16 experiments (numbers 20,21, and 24 to 37 ), the adult leafminers had contact with the canker source plants before the test plants were introduced. In experiments 24 and 25 , the period of contact was $40 \mathrm{~min}$; in experiments 20,21, 26, and 27, it was $2 \mathrm{~h}$; and in experiments 28 to 37 , it was $24 \mathrm{~h}$.

In all experiments except numbers 20 , 23 , and 34 , the test plants were misted with water before being introduced into the boxes, and in all experiments, except numbers 20 and 34 to 37, wounds were made to the test plant shoots using needles to facilitate infection by $X$. axonopodis pv. citri from potentially contaminated adult leafminers. After 5 days, the test plants were placed in the boxes in styrofoam trays. The test plants were assessed for symptoms of citrus canker and the incidence of leafminer damage 15 days after oviposition.

Experimental series III. Three experiments (numbers 38 to 40 ) were conducted to determine whether adult leafminers could become contaminated with $X$. axonopodis pv. citri without causing disease. In each experiment, 80 adult insects raised on healthy plants were released into boxes that contained 40 canker source plants (inoculated as described above) and 40 test plants, all with shoots suitable for oviposition. The plants were misted before they were placed in the boxes. The adult leafminer insects were introduced to the boxes 15 days after the canker source plants were inoculated. The test plants were not mechanically wounded. At 2 to 3 days after insect introduction, 40 adults were collected from each experiment and placed singly into glass vials containing 2 $\mathrm{ml}$ of phosphate buffer and maintained at room temperature overnight, when $0.1 \mathrm{ml}$ of the suspension was plated (three plates/vial) on SYS culture medium with rifampicin $\left(0.5 \mathrm{~g}\right.$ of $\mathrm{NH}_{4} \mathrm{H}_{2} \mathrm{PO}_{4}, 0.5 \mathrm{~g}$ of $\mathrm{K}_{2} \mathrm{HPO}_{4}, 0.2 \mathrm{~g}$ of $\mathrm{MgSO}_{4} 7 \mathrm{H}_{2} \mathrm{O}, 5.0 \mathrm{~g}$ of yeast extract, $5.0 \mathrm{~g}$ of sucrose, $15.0 \mathrm{~g}$ of agar, and rifampicin at $100 \mathrm{mg} /$ liter) and the plates were incubated at $28^{\circ} \mathrm{C}$ for $72 \mathrm{~h}$. To detect bacteria spread by oviposition, in experiment 40, leaves containing eggs (two to three leaves/test plant) were removed and placed into a vial containing $2 \mathrm{ml}$ of phosphate buffer and maintained at room temperature overnight. The suspension (three replicates of $0.1 \mathrm{ml}$ ) were plated on SYS medium with rifampicin (three plates/vial) and incubated at $28^{\circ} \mathrm{C}$ for $72 \mathrm{~h}$. Three days later, all plates were examined for colonies of $X$. axonopodis pv. citri.

Experimental series IV. The three experimental series described above were intended to mimic natural conditions for hypothetical transmission of $X$. axonopodis pv. citri by $P$. citrella. In all of these experiments, the insect was required to acquire the pathogen from one set of plants and transmit it to a second set of plants in order for transmission to occur. A fourth experiment was devised in order to determine whether $P$. citrella adults that were artificially contaminated with high numbers of $X$. axonopodis pv. citri could transmit the bacterium to healthy citrus plants. $P$. citrella adults were collected from the insectary, anesthetized with $\mathrm{CO}_{2}$ gas, and placed in a petri dish that previously had been misted with an atomized suspension of $X$. axonopodis pv. citri at a concentration of $10^{9} \mathrm{CFU} / \mathrm{ml}$. The dish containing the anesthetized $P$. citrella and $X$. axonopodis pv. citri then was placed in a microcosm containing 200 Rangpur lime plants that had been wounded with needles and misted with water. As the insects regained consciousness, they flew off into the foliage for mating and oviposition. 
This experiment was performed twice, with 180 insects in the first trial and 130 insects in the second trial.

Statistical analysis. The mean number of mines per plant, the mean number of leaves containing mines per plant, the total numbers of mines, and the total number of leaves containing mines were recorded. Standard deviations were generated for the sample means. The experimental microcosm system allowed us to estimate the true rate of transmission of citrus canker bacteria by $P$. citrella adults and to put an upper limit on the hypothetical rate of transmission in the event transmission was not observed.

In the experimental microcosm, transmission of citrus canker was accomplished by individual insects, independent of transmission by other individual insects; therefore, the binomial probability density function (26) provided the appropriate model for estimating the rate of transmission: Prob $(X$ transfers $)=C(N, X) \times p^{\mathrm{X}} \times(1$ $-p)^{\mathrm{N}-\mathrm{X}}$, where $p=$ transmission rate, $N=$ number of insects observed, $X=$ number of transmissions observed, and $C(N, X)=$ $N ! /[X ! \times(N-X) !]$.

Experiments in series 1 and II were treated separately for this purpose because the underlying mechanisms of acquisition and transmission in the two experimental series were different. The analysis was carried out using SAS (version 8.0; SAS Institute, Cary, NC).

\section{RESULTS}

No citrus canker symptoms were observed in test plants in either experimental series I or II. This shows that $P$. citrella adults did not act as vectors of $X$. axono- podis pv. citri under the conditions used in these experiments. Oviposition occurred in 18 of the 19 experiments (Table 1) in series $\mathrm{I}$, and the total number of leafminer galleries per experiment and leaves containing mines per experiment ranged from 0 to 207 and from 0 to 128 , respectively. Thus, mating occurred between the adults that emerged from the diseased plants and the females oviposited on the healthy test plants. Emergence of $P$. citrella adults occurred 14 to 15 days after inoculation of the plants with $X$. axonopodis pv. citri, and symptoms of citrus canker on the source plants frequently were present in mines formed by the larvae. Thus, the development and emergence of the adults occurred in the presence of the disease.

In experimental series II, in which newly emerged adult insects reared on healthy citrus were put in simultaneous contact with diseased and healthy plants, mines were produced on test plants in all experiments except number 21 (Table 2). The total number of leaves containing mines/experiment and the total number of mines/experiment ranged from 0 to 210 and 0 to 276, respectively. Oviposition by adults on the test plants occurred from 1 to 2 days after they were released into the boxes.

None of the insects observed in experiment series I or II $(N=1,484$ or 1,635 , respectively) transmitted $X$. axonopodis pv. citri. Therefore, in the binomial probability density function $X=0$ and $C(N, 0)=$ $N ! /(0 ! \times N !)=N ! / N !=1$, regardless of the value of $N$. The probability of observing no transmission events was calculated as Prob (no transmission events) $=p^{0}(1-p)^{\mathrm{N}}$ $=(1-p)^{\mathrm{N}}$ for $N=1,484$ and 1,635 and for assumed transmission rates of 0.0001 to $1.0 \%$ (Tables 3 and 4 ).

The binomial probability distribution using hypothetical rates of transmission suggests that the rate of transmission of citrus canker by $P$. citrella is not likely to be above $0.2 \%$ per oviposition, because if it were above that rate we would have had a $95 \%$ or greater likelihood of observing it in experimental series I and II (Tables 3 and 4). The estimate of $0.2 \%$ as the upper limit for the transmission rate is a conservative estimate.

In experimental series III (experiments 38 to 40), X. axonopodis pv. citri colonies were not observed on the plates inoculated with the phosphate buffer washes of adult insects that had infested canker-infected plants or from leaves that contained the insect.

Transmission of $X$. axonopodis pv. citri to Rangpur lime seedlings was observed in the final experiments, in which the insects were artificially infested with $X$. axonopodis pv. citri at $10^{9} \mathrm{CFU}$ before they were placed in the experimental microcosms (Table 5). In these experiments, leafminer galleries, citrus canker, and leafminer galleries with citrus canker were observed.

\section{DISCUSSION}

Adult leafminers were not found to be a vector for $X$. axonopodis pv. citri in any of the 40 experiments performed in this study in which the insect was required to acquire the pathogen from infected plants in order to transmit it. All experiments were designed to favor pathogen transmission. The experimental design included an extremely high density of susceptible plant material, severe infection of source plants with cit-

Table 1. Leafminer development on citrus plants in 19 trials designed to investigate whether leafminers can act as vectors of Xanthomonas axonopodis pv. citri when the adults developed in and emerged on plants with symptoms of citrus canker

\begin{tabular}{|c|c|c|c|c|c|c|c|}
\hline \multirow[b]{3}{*}{ Exp. no..$^{\mathrm{c}}$} & \multicolumn{3}{|c|}{ Treatment $^{\mathrm{a}}$} & \multicolumn{4}{|c|}{ Leafminer development ${ }^{b}$} \\
\hline & \multirow{2}{*}{$\begin{array}{l}\text { Misted source } \\
\text { plants }\end{array}$} & \multirow{2}{*}{$\begin{array}{l}\text { Misted test } \\
\text { plants }\end{array}$} & \multirow{2}{*}{$\begin{array}{c}\text { Wounded test } \\
\text { plants }\end{array}$} & \multicolumn{2}{|c|}{ Mines/plant } & \multicolumn{2}{|c|}{ Leaves with mines/plant } \\
\hline & & & & Average \pm SD & Total & Average \pm SD & Total \\
\hline 1 & - & - & - & $0.93 \pm 1.03$ & 37 & $0.93 \pm 1.03$ & 37 \\
\hline 2 & - & - & - & $1.83 \pm 1.28$ & 73 & $1.83 \pm 1.28$ & 73 \\
\hline 3 & - & - & - & $1.83 \pm 2.17$ & 73 & $1.55 \pm 1.76$ & 62 \\
\hline 4 & - & + & + & $3.45 \pm 2.98$ & 138 & $2.33 \pm 1.84$ & 93 \\
\hline 5 & + & + & + & $3.10 \pm 2.20$ & 124 & $1.98 \pm 1.31$ & 79 \\
\hline 6 & + & + & - & $3.43 \pm 2.01$ & 137 & $2.75 \pm 1.50$ & 110 \\
\hline 7 & + & + & + & $0.28 \pm 0.71$ & 11 & $0.28 \pm 0.71$ & 11 \\
\hline 8 & - & + & + & $1.88 \pm 2.04$ & 75 & $1.28 \pm 1.30$ & 51 \\
\hline 9 & + & + & + & $1.88 \pm 2.27$ & 75 & $1.23 \pm 1.29$ & 49 \\
\hline 10 & + & + & + & $1.08 \pm 1.39$ & 43 & $1.00 \pm 1.24$ & 40 \\
\hline 11 & - & + & + & $0.73 \pm 1.22$ & 29 & $0.73 \pm 1.22$ & 29 \\
\hline 12 & + & + & + & $0.80 \pm 1.27$ & 32 & $0.73 \pm 1.12$ & 29 \\
\hline 13 & + & + & + & $3.25 \pm 2.65$ & 130 & $2.13 \pm 1.62$ & 85 \\
\hline 14 & + & + & + & $2.10 \pm 2.02$ & 84 & $1.68 \pm 1.49$ & 67 \\
\hline 15 & + & + & + & $2.13 \pm 1.44$ & 85 & $2.00 \pm 1.36$ & 80 \\
\hline 16 & + & + & + & $0.00 \pm 0.00$ & 0 & $0.00 \pm 0.00$ & 0 \\
\hline 17 & + & + & - & $1.68 \pm 2.47$ & 67 & $0.80 \pm 1.03$ & 32 \\
\hline 18 & + & + & - & $5.18 \pm 3.32$ & 207 & $3.20 \pm 1.86$ & 128 \\
\hline 19 & + & + & - & $1.60 \pm 1.71$ & 64 & $1.43 \pm 1.48$ & 57 \\
\hline Totals & $\ldots$ & $\ldots$ & $\ldots$ & $\ldots$ & 1,484 & $\ldots$ & 1,112 \\
\hline
\end{tabular}

a Treatment $=$ mist on canker-infected source plants, mist on test plants, wounded test plants; + or - indicates presence or absence of treatment, respectively.

${ }^{\mathrm{b}} \mathrm{SD}=$ standard deviation.

${ }^{\mathrm{c}}$ Experiment number. 
rus canker, and large numbers of adult leaf miners. The results suggest that citrus canker is not vectored by $P$. citrella adults to any significant degree under these favorable experimental conditions.

Additional factors to enhance infection by $X$. axonopodis pv. citri also were tested. These included the presence or absence of free water on the leaves of canker source and test plants, the presence or absence of wounds on the shoots of test plants, and the duration of access to diseased plants offered to the insects. Free water on the source plants favored exudation of bacterial inoculum from the canker lesions and free water on susceptible test leaves should have facilitated infection. The presence of wounds on the shoots would have facilitated the entry of the bacteria into the plants. All of these factors should have provided excellent conditions for infection $(8,18)$ and, consequently, for the spread of the disease.

Differences in insect activity were observed between experiments. The variation observed in the number of mines produced on the test plants may have occurred due to differences in the fecundity or the rate of mortality of adults in the different experiments. Furthermore, the male:female ratio may have varied, and in experiments 1 to 19 , the number of eggs and first-instar larvae on the canker and leafminer source plants, and their viabilities, may have been different between experiments. This can be inferred by the variation in the number of mines per leaf and mines per plant (Table 1). Similar variation was observed in experiments 20 to 37 (Table 2).

Careful evaluation of plants for symptoms of infection by $X$. axonopodis pv. citri in experiments 1 to 37 confirmed that disease did not develop on plants exposed to adult leafminers and neighboring plants infected with $X$. axonopodis pv. citri. This posed a series of questions that were investigated in the final experiments. First, it was possible that adult insects could acquire $X$. axonopodis pv. citri without subsequent transmission of the pathogen. Therefore, experiments 38 to 40 were conducted to determine whether adult leafminers were becoming contaminated with $X$. axonopodis pv. citri and potentially acting as vectors of the bacterium without infection being observed. $X$. axonopodis pv. citri was not recovered from any in-

Table 3. Probability of observing transmission of citrus canker by oviposition by Phyllocnistis citrella adults that emerged on plants infected with citrus canker based on the binomial probability distribution and different hypothetical rates of transmission ${ }^{\mathrm{a}}$

\begin{tabular}{|c|c|c|}
\hline If true ${ }^{b}$ & $\begin{array}{c}\text { Prob } \\
\text { observe }^{\mathrm{c}}\end{array}$ & $\begin{array}{l}\text { Prob not } \\
\text { observe }^{\mathrm{d}}\end{array}$ \\
\hline $0.001 \%$ & 0.015 & 0.985 \\
\hline $0.005 \%$ & 0.072 & 0.928 \\
\hline $0.01 \%$ & 0.138 & 0.862 \\
\hline $0.05 \%$ & 0.524 & 0.476 \\
\hline $0.1 \%$ & 0.773 & 0.227 \\
\hline $0.2 \%$ & 0.949 & 0.051 \\
\hline $0.25 \%$ & 0.976 & 0.024 \\
\hline $0.5 \%$ & 0.999 & 0.001 \\
\hline $1.0 \%$ & 1.000 & 0.000 \\
\hline
\end{tabular}

a Based on experimental data summarized in Table 1, with $n=1,484$ oviposition events.

b If the hypothetical 'true' rate of transmission is as shown.

${ }^{c}$ Then the probability of observing transmission in our experiment was as shown.

d And the probability of not observing transmission in our experiment was as shown. sects in these experiments. The possibility remained that the external tissues of the adult insect either were highly hydrophobic or possessed bacteriostatic compounds which made the acquisition and transport of bacteria suspended in free water unlikely to occur. These hypotheses were ruled out by the final experiments, in which insects were artificially infested with large numbers of $X$. axonopodis pv. citri. In these experiments, transmission of $X$. axonopodis pv. citri was observed (Table 5), indicating that there are no physical or biochemical barriers that preclude transmission of $X$. axonopodis pv. citri by

Table 4. Probability of observing transmission of citrus canker by oviposition by Phyllocnistis citrella adults that developed in and emerged on healthy plants and given free access to cankerdiseased and healthy plants based on the binomial probability distribution and different hypothetical rates of transmission ${ }^{\mathrm{a}}$

\begin{tabular}{|c|c|c|}
\hline If true ${ }^{b}$ & $\begin{array}{c}\text { Prob } \\
\text { observe }^{\mathrm{c}}\end{array}$ & $\begin{array}{l}\text { Prob not } \\
\text { observe }^{d}\end{array}$ \\
\hline $0.001 \%$ & 0.016 & 0.984 \\
\hline $0.005 \%$ & 0.079 & 0.921 \\
\hline $0.01 \%$ & 0.151 & 0.849 \\
\hline $0.05 \%$ & 0.559 & 0.441 \\
\hline $0.1 \%$ & 0.810 & 0.190 \\
\hline $0.2 \%$ & 0.962 & 0.038 \\
\hline $0.25 \%$ & 0.983 & 0.017 \\
\hline $0.5 \%$ & 1.000 & 0.000 \\
\hline $1.0 \%$ & 1.000 & 0.000 \\
\hline
\end{tabular}

a Based on experimental data summarized in Table 2, with $n=1,635$ oviposition events.

b If the hypothetical 'true' rate of transmission is as shown.

${ }^{c}$ Then the probability of observing transmission in our experiment was as shown.

${ }^{d}$ And the probability of not observing transmission in our experiment was as shown.

Table 2. Leafminer development on citrus plants in 18 trials designed to investigate whether leafminer adults can act as vectors of Xanthomonas axonopodis pv. citri when given free access to diseased and healthy plants

\begin{tabular}{|c|c|c|c|c|c|c|c|}
\hline \multirow[b]{3}{*}{ Exp. no. ${ }^{\mathrm{c}}$} & \multicolumn{3}{|c|}{ Treatment $^{\mathrm{a}}$} & \multicolumn{4}{|c|}{ Leafminer development ${ }^{b}$} \\
\hline & \multirow{2}{*}{$\begin{array}{l}\text { Insects prev. } \\
\text { exposed }\end{array}$} & \multirow{2}{*}{$\begin{array}{l}\text { Misted test } \\
\text { plants }\end{array}$} & \multirow{2}{*}{$\begin{array}{l}\text { Wounded test } \\
\text { plants }\end{array}$} & \multicolumn{2}{|c|}{ Mines/plant } & \multicolumn{2}{|c|}{ Leaves with mines/plant } \\
\hline & & & & Average \pm SD & Total & Average \pm SD & Total \\
\hline 20 & + & - & - & $0.83 \pm 0.92$ & 33 & $0.83 \pm 0.92$ & 33 \\
\hline 21 & + & + & + & $0.00 \pm 0.00$ & 0 & $0.00 \pm 0.00$ & 0 \\
\hline 22 & - & + & + & $0.48 \pm 0.71$ & 19 & $0.48 \pm 0.71$ & 19 \\
\hline 23 & - & - & + & $0.55 \pm 1.09$ & 22 & $0.45 \pm 0.86$ & 18 \\
\hline 24 & + & + & + & $0.45 \pm 0.86$ & 18 & $0.45 \pm 0.86$ & 18 \\
\hline 25 & + & + & + & $0.33 \pm 0.75$ & 13 & $0.33 \pm 0.75$ & 13 \\
\hline 26 & + & + & + & $5.58 \pm 3.69$ & 223 & $3.65 \pm 2.09$ & 146 \\
\hline 27 & + & + & + & $0.58 \pm 1.07$ & 23 & $0.58 \pm 1.07$ & 23 \\
\hline 28 & + & + & + & $1.98 \pm 2.06$ & 79 & $1.75 \pm 1.94$ & 70 \\
\hline 29 & + & + & + & $3.45 \pm 2.77$ & 138 & $2.35 \pm 1.61$ & 94 \\
\hline 30 & + & + & + & $1.68 \pm 2.31$ & 67 & $1.43 \pm 1.87$ & 57 \\
\hline 31 & + & + & + & $2.60 \pm 2.04$ & 104 & $2.45 \pm 1.95$ & 98 \\
\hline 32 & + & + & + & $2.75 \pm 3.00$ & 110 & $1.93 \pm 1.80$ & 77 \\
\hline 33 & + & + & + & $1.20 \pm 2.70$ & 48 & $1.10 \pm 2.38$ & 44 \\
\hline 34 & + & - & - & $5.68 \pm 4.31$ & 227 & $3.40 \pm 2.32$ & 136 \\
\hline 35 & + & + & - & $4.18 \pm 2.64$ & 167 & $3.75 \pm 2.51$ & 150 \\
\hline 36 & + & + & _- & $6.90 \pm 3.69$ & 276 & $5.25 \pm 2.73$ & 210 \\
\hline 37 & + & + & - & $1.70 \pm 2.20$ & 68 & $1.65 \pm 2.18$ & 66 \\
\hline Totals & $\ldots$ & $\ldots$ & $\ldots$ & $\ldots$ & 1,635 & $\ldots$ & 1,272 \\
\hline
\end{tabular}

${ }^{\mathrm{a}}$ Treatment $=$ insects exposed to source plants before test plants, misted test plants, wounded test plants; + or - indicates presence or absence of treatment, respectively.

${ }^{\mathrm{b}} \mathrm{SD}=$ standard deviation

${ }^{\mathrm{c}}$ Experiment number. 
Table 5. Leafminer and citrus canker development on Rangpur lime plants infested with Phyllocnistis citrella adults that had been artificially contaminated with Xanthomonas axonopodis pv. citri at $10^{9}$ $\mathrm{CFU} / \mathrm{ml}^{\mathrm{a}}$

\begin{tabular}{lccc}
\hline & \multicolumn{3}{c}{ Leafminer development $^{\mathbf{b}}$} \\
\cline { 2 - 4 } Experiment number & Leaves with mines & Leaves with canker & Canker in mines \\
\hline 1 & 140 & 89 & 13 \\
2 & 103 & 12 & 2 \\
\hline
\end{tabular}

a All test plants were both wounded and misted with water prior to the introduction of the inoculated insects. Two hundred Rangpur lime plants were used in each trial, with 180 and 130 adult $P$. citrella insects in the two trials, respectively.

b Number of leaves observed with mines, with canker, and with canker in the mines.

P. citrella. Taken together, the data suggest that the failure of $P$. citrella to transmit $X$. axonopodis pv. citri under the conditions of experiments 1 to 37 was due to a failure to acquire the pathogen from plants with symptoms of citrus canker under conditions that favored both inoculum production and infection (free water and wounding of plants).

Despite the fact that no transmission of $X$. axonopodis pv. citri was observed in experiments 1 to 37 , we cannot completely exclude the possibility that acquisition and transmission may occur in nature at a low rate. We used the binomial probability distribution to put an upper limit on the hypothetical rate of transmission of $X$. axonopodis pv. citri by $P$. citrella in two of the experimental series described. The binomial probability distribution analysis suggests that the rate of transmission of citrus canker by $P$. citrella by oviposition is unlikely to be above $0.2 \%$, because, if it were above that rate, we would have had a $95 \%$ or greater likelihood of observing it in both experimental series I and II. Because the underlying mechanisms of contamination, vector movement, and infection in the two experiment series differed, the data from the two series cannot be simply combined to put an upper limit on the rate of vectoring of $X$. axonopodis pv. citri by the citrus leafminer. Nonetheless, the lack of observed symptoms of citrus canker (Tables 1 and 2) suggests that the rate is likely to be very low. Finally, it is important to note that the data in Tables 3 and 4 considers transmission by oviposition only. In experiments 1 to 37 , the majority of test plants were wounded to facilitate infection by bacteria casually contaminating the insect. Such casual transmission of $X$. axonopodis pv. citri predominated, as opposed to transmission associated with oviposition, when insects were artificially contaminated with $X$. axonopodis pv. citri (Table 5). Overall, the complete lack of transmission in the absence of artificially contaminating the insects suggests the estimate of $0.2 \%$ as the upper limit for the transmission rate is a conservative one and the true rate of transmission is likely lower.

The rapid increase in citrus canker incidence observed in Brazil (10) and other countries (12) after the introduction of $P$. citrella should not be attributed primarily to adult leafminers acting as vectors of the bacteria, although the results of experiments 41 and 42 (Table 5) demonstrate that this is possible. Instead, the larval stages, by creating abundant hypersusceptible tissue in the form of miner galleries, greatly increases the infection potential for the pathogen. This is consistent with hypotheses discussed in the literature (12) and results obtained in the laboratory (4).

\section{ACKNOWLEDGMENTS}

We thank C. Bock for an especially helpful review of the manuscript.

\section{LITERATURE CITED}

1. Achor, D. S., Browning, H. W., and Albrigo L. G. 1996. Anatomical and histological modifications in citrus leaves caused by larval feeding of citrus leafminer (Phyllocnistis citrella Staint). Page 69 in: Proc. Int. Conf. Citrus Leafminer. University of Florida, Orlando.

2. Badawy, A. 1967. The morphology and biology of Phyllocnistis citrella Stainton, a citrus leaf-miner in the Sudan. Bull. Soc. Entomol. Egypt 51:95-103.

3. Chagas, M. C. M., and Parra, J. R. P. 2000. Phyllocnistis citrella Stainton (Lepidoptera: Gracillariidae): técnica de criação e biologia em diferentes temperaturas. Ann. Soc. Entomol. Bras. 29:227-235.

4. Chagas, M. C. M., Parra, J. R. P., Namekata, T., Hartung, J. S., and Yamamoto, P. T. 2001. Phyllocnistis citrella Stainton (Lepidoptera: Gracillariidae) and its relationship with the citrus canker bacterium Xanthomonas axonopodis pv. citri in Brazil. Neotrop. Entomol. 1:5559.

5. Clausen, C. P. 1931. Two citrus leafminers of the far east. (U. S. Dep. Agric. Tech. Bull. 252). Rev. Appl. Entomol. 19:649.

6. Cook, A. A. 1988. Association of citrus canker pustules with leaf miner tunnels in North Yemen. Plant Dis. 72:546.

7. Danós, E., Berger, R. D., and Stall, R. E. 1984. Temporal and spatial spread of citrus canker within groves. Phytopathology 74:904-908.

8. Egel, D. S., Graham, J. H., and Riley, T. D. 1991. Population dynamics of strains of Xanthomonas campestris differing in aggressiveness on Swingle citrumelo and grapefruit. Phytopathology 81:666-671.

9. Garijo, C., and Garcia, E. J. 1994. Phyllocnistis citrella (Stainton, 1856) (Insecta: Lepidoptera: Gracillariidae: Phyllocnistinae) en los cultivos de cítricos de Andalucía (Sur España): Biología, ecología y control de la praga. Bol. Sanidad Veg. Plagas 20:815-816.

10. Gimenes-Fernandes, N., Barbosa, J. C., Ayres, A. J., and Massari, C. A. 2000. Plantas doentes não detectadas nas inspeções dificultam a erradicação do cancro cítrico. Summa Phytopa- thol. 26:320-325.

11. Gottwald, T. R., Graham, J. H., and Riley, T. D. 1997. The influence of spray adjuvants on exacerbation of citrus bacterial spot. Plant Dis. 81:1305-1310.

12. Gottwald, T. R., Graham, J. H., and Schubert, T. S. 1997. An epidemiological analysis of the spread of citrus canker in urban Miami, Florida, and synergistic interaction with Asian citrus leafminer. Fruits 52:383-390.

13. Gottwald, T. R., Hughes, G., Graham, J. H., Sun, X., and Riley, T. 2001. The citrus canker epidemic in Florida: the scientific basis of regulatory eradication policy for an invasive species. Phytopathology 91:30-34.

14. Gottwald, T. R., McGuire, R. G., and Garran, S. 1988. Asiatic citrus canker: Spatial and temporal spread in simulated new planting situations in Argentina. Phytopathology 78:739-745.

15. Gottwald, T. R., Timmer, L. W., and McGuire, R. G. 1989. Analysis of disease progress of citrus canker in nurseries in Argentina. Phytopathology 79:1276-1283.

16. Graham, J. H., Gottwald, T. R., Browning, H. W., and Achor, D. S. 1996. Citrus leafminer exacerbated the outbreak of Asiatic citrus canker in South Florida. Page 83 in: Proc. Int. Conf. Citrus Leafminer. University of Florida, Orlando.

17. Graham, J. H., Gottwald, T. R., Cubero, J., and Achor, D. S. 2004. Xanthomonas axonopodis pv. citri: factors affecting successful eradication of citrus canker. Mol. Plant Pathol. 5:1-15.

18. Graham, J. H., Gottwald, T. R., and Fardelmann, D. 1990. Cultivar-specific interactions for strains of Xanthomonas campestris from Florida that cause citrus canker and citrus bacterial spot. Plant Dis. 74:753-756.

19. Heppner, J. B. 1993. Citrus leafminer, Phyllocnistis citrella, in Florida (Lepidoptera Gracillariidae: Phyllocnistinae). Trop. Lepid. 4:49-64.

20. Koizumi, M., Kimijima, E., Tsukamoto, T., Togawa, M., and Masui, S. 1996. Dispersal of citrus canker bacteria in droplets and prevention with windbreaks. Proc. Int. Soc. Citricult 1:340-344.

21. Prates, H. S., Nakano, O., and Gravena, S. 1996. "Minadora das folhas dos citros" Phyllocnistis citrella, Stainton, 1856. CATI, Comunicado Técnico, 129. Campinas, S.P., Brazil.

22. Schoulties, C. L., Civerolo, E. L., Miller, J. W. Stall, R. E., Krass, C. J., Poe, S. R., and DuCharme, E. P. 1987. Citrus canker in Florida. Plant Dis. 71:388-395.

23. Sohi, G. S., and Sandhu, M. S. 1968. Relationship between Citrus leaf-miner (Phyllocnistis citrella Stainton) injury and Citrus canker [Xanthomonas citri (Hasse) Dowson] incidence on Citrus leaves. J. Res. Punjab Agric. Univ. 5:66-69.

24. Stall, R. E., and Civerolo, E. L. 1991. Research relating to the recent outbreak of citrus canker in Florida. Annu. Rev. Phytopathol. 29:399420.

25. Stall, R. E., and Seymour, C. P. 1983. Canker, a threat to citrus in the gulf-coast states. Plant Dis.. 67:581-585.

26. Steel, R. G. D., Torrie, J. H., and Dickey, D. A. 1996. Principles and Procedures of Statistics: A Biometrical Approach. McGraw-Hill, New York.

27. Vauterin, L., Hoste, B., Kersters, K., and Swings, J. 1995. Reclassification of Xanthomonas. Int. J. System. Bacteriol. 45(3):472489.

28. Venkateswarlu, C., and Ramapandu, S. 1992. Relationship between incidence of canker and leafminer in acid lime and sathgudi sweet orange. Indian Phytopathol. 45:227-228. 